\title{
THE OPTIMUM USE OF DIFFERENT MILLING PRODUCTS OF DURUM WHEAT IN PRODUCING SOME BAKERY PRODUCTS
}

\author{
AHMED M. KHORSHID, NADIA, H.A. ASSEM, NADIA, \\ M. ABD-EL-MOTALEB AND JERMINE, S. FAHIM \\ Bread and Pastry Res. Dept., Food Tech. Research Institute, Agric. Res. Center. Giza \\ (Manuscript received 2 August 2010)

\begin{abstract}
Five fractions from milled durum wheat were obtained [two types of semolina (S1 and S2), two types of flour (F1 and F2) and fine bran] in order to find a new use for these fractions to produce some bakery products such as pan and balady bread, biscuits and noodles. From obtained data it could be noticed that all products had good acceptability for all parameters when compared with control sample. Also, chemical composition and cooking quality properties of noodles were evaluated.
\end{abstract}

\section{INTRODUCTION}

Cereal and cereal products are widely consumed as a source of energy as well as protein. Pasta is the second to bread in world consumption. Its nearly world wide acceptance is attributed to its low cost, ease of preparation, versatility, sensory attributes and long shelf life (Mariani and Consta, 1988).

Noodles are among the most important major staple foods in many countries especially the Asian countries (Huang and Morrison, 1988). Thus, about $40-50 \%$ of the wheat consumed in Asian countries is used in noodle production (Oda, 1982).

Instant noodles generally refer to the steamed and deep-fat fried products made from wheat flour, water and some additional materials where it is classified as fried noodles in Korea or instant Chinese type noodles in Japan, which are called commercially "ramen" in Japan and "ramyon" in Korea. However, in a recent trend in Japan the term ramen also is used for the "yellow alkaline" noodles which are not fried (Shin and Kim, 2003).

Durum wheat flour is the preferred raw material for noodles production since it is very hard and can be processed into semolina. It also requires less water compared to other wheat flour to form a dough (Boyacioglu and D'Appolonia, 1994a).

While, soft wheat flour is the main raw material for making balady bread. Possibility of using durum wheat flour in making bread which could increase the utilization and value-added potential of durum wheat in domestic and export markets.

This study was carried out to investigate the possibility of untraditional use of the different milling products of durum wheat to produce some bakery products such 
as pan bread, balady bread, biscuits and noodles. Also, chemical composition and sensory evaluation of these processed products were determined.

\section{MATERIALS AND METHODS}

\subsection{Materials}

2.1.1 Durum wheat: was milled at Regina Company, Sadat City, Egypt, and five fractions were obtained: two types of semolina (fine and coarse semolina), two types of flour (white flour and dark flour) and fine bran.

2.1.2 Wheat flour ( $72 \%$ and $82 \%$ extraction): were obtained from South Cairo Mills Co., Egypt.

2.1.3 Other materials: salt, dry yeast, egg, butter, vanilia and sugar were obtained from local supermarket.

\subsection{Methods}

\subsubsection{Chemical analysis}

Moisture, protein, ash, crude fiber and ether extract were determined according to the method described in A.O.A.C. (2000). Total carbohydrate was calculated by differences.

\subsubsection{Technological methods}

\subsubsection{Baking techniques}

Pan bread was prepared according to the method described by A.A.C.C. (1995). While, balady bread was produced according to the method described by Atia, 1986. Also, biscuits were prepared according to the method described by Smith (1997). Noodles were processed according to the method described by Ali (1998).

\subsubsection{Determination of cooking quality of noodles}

Cooking quality was determined according to the method described by Park et al. (2004).

\subsubsection{Sensory evaluation}

All samples were evaluated by ten panelists from the Bread and Pastry Res. Dept. staff in Food Tech. Res. Institute, Agric. Res. Center. Quality score for pan bread included taste (20), flavor (15), crumb distribution (15), color of crumb (15), color of crust (15) and general appearance (20). The procedure technique was carried out as mentioned by Kralmer and Twigg (1962).

Evaluation of balady bread quality included: taste (20), flavor (15), crumb distribution (15), color of crumb (15), color of crust (15) and general appearance (20) as described by Atia (1986). 
Also, Evaluation of biscuits quality included: taste (20), odor (20), texture (20), stickness (20), color of texture (10) and color of crust (10) as described by Assem and Abd-El-Motaleb (2004).

Noodles quality was evaluated according to Galvez and Resurrecion (1990) which includes: appearance (20), color (20), texture tenderness (25), flavor (20) and stickness (15).

\section{RESULTS AND DISCUSSION}

\subsection{Chemical composition of durum wheat fractions}

Results presented in Table (1) showed the chemical composition of different fractions of durum wheat on dry weight basis. From these data it could be noticed that durum wheat flour had the highest values in protein $(16.83 \%)$, ether extract $(3.17 \%)$ and ash content (2.03\%). While, it was found that fine bran had high content of fiber. Also, it could be noticed that flours (F1 and F2) had the lowest protein content. These data are confirmed with those obtained by Boyacioglu and D'Appolonia (1994b).

Table 1. Chemical composition of durum wheat fractions (on dry weight basis).

\begin{tabular}{|l|c|c|c|c|c|c|}
\hline \multirow{2}{*}{$\begin{array}{c}\text { Chemical } \\
\text { composition }\end{array}$} & Durum & \multicolumn{5}{|c|}{ Durum wheat fractions } \\
\cline { 3 - 7 } & whole & Fine & Coarse & White & Dark & Fine \\
& meal & semolina & semolina & flour & flour & bran \\
& & S1 & S2 & F1 & F2 & \\
\hline Protein & 16.83 & 15.71 & 15.72 & 11.21 & 11.40 & 12.30 \\
Ether extract & 1.96 & 1.57 & 1.60 & 1.33 & 1.62 & 2.60 \\
Ash & 2.03 & 0.67 & 0.68 & 0.80 & 1.02 & 1.81 \\
Crude fiber & 2.41 & 0.72 & 0.72 & 0.91 & 0.98 & 3.52 \\
Total carbohydrates & 76.77 & 81.33 & 81.28 & 85.75 & 83.98 & 79.74 \\
\hline
\end{tabular}

\subsection{Chemical composition of products made from durum wheat fractions}

From the obtained results in table (2), it could be observed that the chemical composition of pan bread produced from flour types (F1) had slight increase in fiber and ash contents when compared with control samples produced from flour (72\% extraction). These data are confirmed with those obtained by Dowedar (2001).

While, balady bread had slight decrease in protein content comparing with control sample ( $82 \%$ extraction). These findings are in line with those obtained by Mekhael (2004) who found that all blends containing durum wheat flour varieties Beni Suef 3 and Suhag 3 had high protein content than the control sample. 
As can be seen the chemical composition of produced noodles had no difference in all compounds between the two types of semolina (S1 and S2). Results reported herein are in agreement with those of Assem (2007).

On the other hand, it could be noticed that adding $20 \%$ fine bran to $80 \%$ flour type (F1) to produce biscuits, increased the ash and fiber contents when compared with biscuits prepared from flour type (F1) and biscuits made from flour 72\% extraction (as control). These results are confirmed with those obtained by Assem and Abd-el motaleb (2004). While, there weren't significant differences in protein and ether extract contents for all types of biscuits.

Table 2. Chemical composition of products made from durum wheat fractions.

\begin{tabular}{|l|c|c|c|c|c|}
\hline \multirow{2}{*}{\multicolumn{1}{|c|}{ Samples }} & \multicolumn{5}{|c|}{ Components } \\
\cline { 2 - 6 } & protein & $\begin{array}{c}\text { Ether } \\
\text { extract }\end{array}$ & Ash & $\begin{array}{c}\text { Crude } \\
\text { fiber }\end{array}$ & $\begin{array}{c}\text { Total } \\
\text { carbohydrates }\end{array}$ \\
\hline Pan bread from wheat flour & 10.62 & 1.25 & 0.59 & 0.62 & 86.92 \\
(72\%extraction) & 10.13 & 1.12 & 0.88 & 0.90 & 86.97 \\
Pan bread from (F1) & 12.35 & 1.39 & 1.46 & 1.67 & 83.16 \\
\hline Balady bread from wheat flour & & & & & \\
(82\%extraction) & 11.85 & 1.41 & 1.45 & 1.63 & 80.66 \\
Balady bread from (F2) & 15.64 & 1.52 & 0.60 & 0.58 & 81.66 \\
\hline Noodles from (S1) & 15.68 & 1.56 & 0.61 & 0.64 & 81.51 \\
Noodles from (S2) & 10.21 & 18.23 & 1.03 & 1.64 & 68.89 \\
\hline Biscuits from (72\% extraction) & 9.18 & 18.20 & 1.03 & 1.22 & 70.37 \\
Biscuits from 100\%(F1) & 9.71 & 18.83 & 1.35 & 1.90 & 68.21 \\
Biscuits from: & & & & & \\
(80\% F1+20\% fine bran) & & & & & \\
\hline
\end{tabular}

\subsection{Sensory evaluation of products made from durum wheat fractions}

The results concerning sensory evaluation of pan and balady bread produced from flour type (F1 and F2), respectively, were illustrated in tables (3 and 4). It could be observed that samples of pan bread prepared from flour (F1) had good acceptability for all parameters when compared with control sample.

However, balady bread had very good acceptance when compared with control sample. Results reported herein are in agreement with those of Mekhael (2004) who found that there was no significant difference between balady bread made from wheat flour (82\% extraction) as control sample comparing with bread made from $100 \%$ durum wheat flour. 
Table (5) showed the sensory properties of biscuits prepared from $100 \%$ flour type (F1) and $80 \%$ F1+20\%fine bran, which had very good grade for all parameters for all kinds of biscuits compared with control sample. Similar findings were observed by Assem and Abd-El-Motaleb (2004).

Table 3. Sensory evaluation of pan bread produced from flour type (F1).

\begin{tabular}{|c|c|c|c|c|c|c|c|c|}
\hline $\begin{array}{c}\text { Pan bread } \\
\text { samples }\end{array}$ & $\begin{array}{c}\text { General } \\
\text { Appearance } \\
\mathbf{( 2 0 )}\end{array}$ & $\begin{array}{c}\text { Color } \\
\text { of } \\
\text { crust } \\
\mathbf{( 1 5 )}\end{array}$ & $\begin{array}{c}\text { color } \\
\text { of } \\
\text { crum } \\
\mathbf{b} \\
\mathbf{( 1 5 )}\end{array}$ & $\begin{array}{c}\text { Crumb } \\
\text { distribution } \\
\mathbf{( 1 5 )}\end{array}$ & $\begin{array}{c}\text { Flavor } \\
\mathbf{( 1 5 )}\end{array}$ & $\begin{array}{c}\text { Taste } \\
\mathbf{( 2 0 )}\end{array}$ & $\begin{array}{c}\text { Overall } \\
\text { scores } \\
\mathbf{( 1 0 0 )}\end{array}$ & Grade \\
\hline $\begin{array}{c}\text { Control } \\
\text { (72\%ex.) }\end{array}$ & 19.0 & 15.0 & 14.0 & 14.5 & 15.0 & 20.0 & 97.0 & V.G. \\
Flour (F1) & 15.0 & 14.5 & 13.5 & 14.0 & 14.0 & 17.0 & 88.0 & G. \\
\hline
\end{tabular}

$90-100$ (Very good), $80-89$ (Good), $70-79$ (satisfactory) and less than 70 questionable.

Table 4. Sensory evaluation of balady bread produced from flour type (F2).

\begin{tabular}{|c|c|c|c|c|c|c|c|c|}
\hline $\begin{array}{c}\text { Balady } \\
\text { bread } \\
\text { samples }\end{array}$ & $\begin{array}{c}\text { General } \\
\text { Appearance } \\
\mathbf{( 2 0 )}\end{array}$ & $\begin{array}{c}\text { Color } \\
\text { of } \\
\text { crust } \\
\mathbf{( 1 5 )}\end{array}$ & $\begin{array}{c}\text { Color } \\
\text { of } \\
\text { crumb } \\
\mathbf{( 1 5 )}\end{array}$ & $\begin{array}{c}\text { Crumb } \\
\text { distribution } \\
\mathbf{( 1 5 )}\end{array}$ & $\begin{array}{c}\text { Flavor } \\
\mathbf{( 1 5 )}\end{array}$ & $\begin{array}{c}\text { Taste } \\
\mathbf{( 2 0 )}\end{array}$ & $\begin{array}{c}\text { Overall } \\
\text { scores } \\
(\mathbf{1 0 0}\end{array}$ & Grade \\
\hline $\begin{array}{l}\text { Control } \\
\mathbf{( 8 2 \% e x . )}\end{array}$ & 19.0 & 14.5 & 14.5 & 14.0 & 14.5 & 19.0 & 95.5 & V.G. \\
Flour (F2) & 19.0 & 14.0 & 14.5 & 13.5 & 14.0 & 18.0 & 93.0 & V.G. \\
\hline
\end{tabular}

$90-100$ (Very good), $80-89$ (Good), $70-79$ (satisfactory) and less than 70 questionable.

Table 5. Sensory evaluation of biscuits produced from F1 and F1 plus fine bran.

\begin{tabular}{|l|c|c|c|c|c|c|c|c|}
\hline Biscuit samples & $\begin{array}{c}\text { Color } \\
\text { of } \\
\text { crust } \\
(\mathbf{1 0})\end{array}$ & $\begin{array}{c}\text { Color } \\
\text { of } \\
\text { texture } \\
(\mathbf{1 0})\end{array}$ & $\begin{array}{c}\text { Stickness } \\
\mathbf{( 2 0 )}\end{array}$ & $\begin{array}{c}\text { Texture } \\
\mathbf{( 2 0 )}\end{array}$ & $\begin{array}{c}\text { odor } \\
\mathbf{( 2 0 )}\end{array}$ & $\begin{array}{c}\text { Taste } \\
\mathbf{( 2 0 )}\end{array}$ & $\begin{array}{c}\text { Overall } \\
\text { scores } \\
\mathbf{( 1 0 0 )}\end{array}$ & Grade \\
\hline $\begin{array}{l}\text { Control from } \\
\text { wheat flour } \\
\text { (72\%ex.) } \\
\text { Flour (F1) }\end{array}$ & 10.0 & 9.0 & 20.0 & 19.0 & 20.0 & 20.0 & 98.0 & V.G. \\
$\begin{array}{l}\mathbf{( 8 0 \%} \text { F1)+ } \\
\mathbf{2 0 \%} \text { fine bran }\end{array}$ & 9.0 & 8.5 & 19 & 18.5 & 19.0 & 19.5 & 93.5 & V.G. \\
\hline
\end{tabular}

90 - 100 (Very good), 80 -89 (Good), 70 -79 (satisfactory) and less than 70 questionable.

Table (6) illustrated the sensory evaluation of fried instant noodles produced from semolina (S1 and S2) had no difference in flavor, and noodles from (S2) had slightly decrease in all quality parameters when comparing with noodles produced from (S1). Both kinds had very good grade. These data are confirmed with those obtained with Galvez and Resurreccion (1990). 
Table 6. Sensory evaluation of noodles produced from S1 and S2.

\begin{tabular}{|c|c|c|c|c|c|c|}
\hline samples & Appearance & color & $\begin{array}{c}\text { Texture } \\
\text { tenderness }\end{array}$ & Flavor & Stickiness & $\begin{array}{c}\text { Overall } \\
\text { scores } \\
\text { (20) }\end{array}$ \\
$\mathbf{( 2 0 )}$ & $\mathbf{( 2 5 )}$ & $\mathbf{( 2 0 )}$ & $\mathbf{( 1 5 )}$ & $\mathbf{( 1 0 0 )}$ \\
\hline Noodles from (S1) & 20.0 & 20.0 & 24.0 & 20.0 & 14.0 & 98.0 \\
Noodles from (S2) & 18.0 & 18.5 & 22.5 & 20.0 & 12.5 & 91.5 \\
\hline
\end{tabular}

90 - 100 (Very good), $80-89$ (Good), 70 -79 (satisfactory) and less than 70 questionable.

\subsection{Cooking quality properties of noodles}

The effect of producing noodles from S1 and S2 fractions on cooking properties in terms of weight gain, cooking loss and volume gain was reported in table (7). It could be noticed that the weight gain, cooking loss and volume gain of (S2) were increased compared with those of (S1) from $184 \%$ to $187 \%$, from $3.49 \%$ to $3.63 \%$ and from $190 \%$ to $193 \%$, respectively. these results are similar with those obtained by Zahran et al., (2004) and Abd El-Khalek (2005) .

Table 7. Cooking quality of noodles produced from S1 and S2 :

\begin{tabular}{|l|c|c|c|}
\hline samples & $\begin{array}{c}\text { Weight gain } \\
\text { \% }\end{array}$ & $\begin{array}{c}\text { Cooking loss } \\
\%\end{array}$ & $\begin{array}{c}\text { Volume gain } \\
\%\end{array}$ \\
\hline Noodles from (S1) & 184 & 3.49 & 190 \\
Noodles from (S2) & 187 & 3.63 & 193 \\
\hline
\end{tabular}

From the mentioned results, it could be said that, there is a probability of success of untraditional use for the different milling products of durum wheat to produce some bakery products such as pan and balady bread, biscuits and noodles.

\section{REFERENCES}

1. A.A.C.C. 1995. American Association of Cereal Chemists ( $9^{\text {th }}$ ED). Method 54: 21, Final Approval November 1995. Ins., St. Paul, Minnesota, U.S.A.

2. Abd El-Khalek, A.M. 2005. Production of noodles from different flours of various extractions. M.Sc. Thesis, Food Tech. Dept., Fac. of Agric., Banha Univ., Egypt.

3. Ali, M.S. 1998. Production and evaluation of instant fried noodles. M.Sc.Thesis, Food Tech. Dept., Fac. of Agric., Cairo Univ., Egypt.

4. A.O.A.C. 2000. Official Methods of Analysis of Association of Official Analytical Chemists, 7Ed, published by Association of Official Analytical chemists, U.S.A.

5. Assem, N.H.A. and N.M. Abd-El-Motaleb. 2004. Preparation and evaluation of different biscuits containing barley flour, malt syrup and malt flour. J. Agric. Res., 82 (3). 
6. Assem, N.H.A. 2007. Evaluation of spaghetti supplemented with defatted soybean and wheat germ flour. Minufiya J. Agric. Res., vol. 32 (3): 771- 778.

7. Atia, A.A. 1986. Physical and chemical studies on the staling of some Egyptian bread. Ph.D. in Food Science, Cairo Univ., Egypt.

8. Boyacioglu, M.H. and B.L. D'Appolonia. 1994a. Characterization and utilization of durum wheat for bread making. 1- comparison of chemical, rheological and baking properties between bread wheat flours and durum wheat flours. Cereal Chem., 71: 21-28.

9. Boyacioglu, M.H. and B.L. D'Appolonia. 1994b. Durum wheat and bread produces. Cereal Food World. 39: 168-174.

10. Dowedar, M.M. 2001. Chemical and physical studies on some natural resources used in improving bakery products. Ph.D. Thesis, Fac. of Agric., Cairo Univ., Egypt.

11. Galvez, F.F. and A.V. Resurreccion. 1990. Comparison of three descriptive analysis scaling methods for the sensory evaluation of noodles. J. of Sensory Studies, 5: 251-263.

12. Huang, S. and W.R. Morrison. 1988. Aspects of protein in Chinese and British common (hexaploid)wheat related to the quality of white and yellow Chinese noodles. J. Cereal Sci., 8: 177-187.

13. Kralmer, A. and B.A. Twigg. 1962. Fundamentals of quality control for the food industry. AV1 publishing Co. West port, C.T. PP. 512.

14. Mariani, M. and A.Consta. 1988. Image and nutritional role of pasta in changing food patterns. In Durum Chemistry and Technology. G. Fabriani and C. Lintas, eds. Am. Assoc. Cereal Chem. St. Paul, MN, USA.

15. Mekhael, E.K.G. 2004. Biochemical and technological studies on balady bread made from durum wheat mixed with some cereals and cereal by products. M.Sc. Thesis, Food Tech. Dept., Fac. of Agric., Cairo Univ., Egypt.

16. Oda, M. 1982. Men no hon (A book about noodles), 2nd ed., Shokuhin Sangyo Shinbunsha.

17. Park, C.S., B.H. Hong and B.K. Baik. 2004. Cooking time of white salted noodles and its relationship with protein and amylase contents of wheat. Cereal Chem., 81 (2): 165-171.

18. Shin, S.N. and S.K. Kim. 2003. Properties of instant noodles flour produced in Korea. Cereal Food World, 48 (6): 310-314.

19. Smith, W.H. 1997. Biscuits crackers and cookies. 1st ed., Applied Science Puplishers, LTD, London, vol. 1.

20. Zahran, G.A.H., Abd El-Motaleb, M. Nadia and S. Shams, Omaima. 2004. Chemical and biological functional aspects of pasta rich in dietary fiber and $\beta$-glucan. Egypt J. Agric. Res., 82 (3): 13-25. 


\section{التوجيه الأمثل لمختلف نواتج طحن قمح الديورم فى انتاج بعض منتجات المخابز}

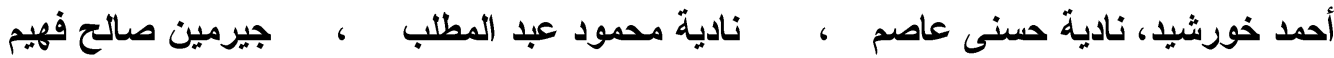

$$
\text { قسم بحوث الخبز والعجائن - معرج بحوث تكنولوجيا الأغذية- مركز البحوث الزراعية - جيزة }
$$

تم الحصول على خمسة نو اتج من نو اتج طحن قمح الديورم ( نوعين من السيمولينا، نوعين

من الدقيق، ردة ناعمة) وذلك لايجاد استخدامات جديدة لهذه النواتج فى انتاج بعض منتجات المخابز مثل الخبز الافرنجى (خبز القو الب)، الخبز البلدى، البسكويت، النودلز.

ومن خلال النتائج المتحصل عليها أمكن ملاحظة ان كل المنتجات كان لها قبول جيد بالمقارنة بالعينات الكنترول. ايضا تم تقدير التركيب الكيماوى، وصفات جودة الطبخ للنودلز . 